\title{
IMPLEMENTATION OF “9P MARKETING MIX” ON OUT-PATIENT SERVICE AT ISLAMIC HOSPITAL JEMURSARI, SURABAYA, EAST JAVA
}

\author{
Satriya Wijaya, Agus Aan Adriansyah
}

Study Program of Public Health, Faculty of Public Health, Universitas Nahdlatul Ulama

\begin{abstract}
Background: Hospitals are facing several threats like increasing competition, rising costs, and image problems that can threaten their existence. Hospitals need to adopt a market-based model centered on transparency, accountability for outcomes, and customer choice. Marketing mix is a set of tools available to an organization to shape the nature of its offer to customers. This study aimed to investigate the implementation of " $9 p$ marketing mix" on out-patient service at Islamic Hospital Jemursari, Surabaya.

Subjects and Method: This was a descriptive study conducted at Islamic Hospital Jemursari, Surabaya, East Java. A sample of 87 patiens was selected for this study. The dependent variable was "9P marketing mix", consisiting of product, price, place, promotion, people, process, physical appearance, public relation, and power. The data were collected by questionnaire and analyzed accordingly.

Results: The extent to which the nine variables of marketing mix meeting the patient expectation were as follows: product $(60.9 \%)$, price $(86.2 \%)$, place $(67.8 \%)$, promotion (74.7\%), people $(57.5 \%)$, process $(62.1 \%)$, physical appearance $(69.0 \%)$, public relation (80.5\%), and power (81.6\%).

Conclusion: The extent to which the nine variables of marketing mix meeting the patient expectation are varying.

Keywords: 9P marketing mix, out-patient, hospital

\section{Correspondence:}

Satriya Wijaya. Study Program of Public Health, Faculty of Public Health, Universitas Nahdlatul Ulama, Surabaya, East Java. Email: aan.naufal87@unusa.ac.id. Mobile: o81335320959.
\end{abstract}

